\title{
Ungdomsvård som dokusåpa
}

\author{
TORBJÖRN FORKBY
}

\begin{abstract}
I artikeln behandlas en framställning av ungdomsvård i televisionen. Författaren analyserar hur samhällsprogrammet Kalla faktas skildring av en så kallad värstingseglats har påverkats av att den influerats av en underhällningsgenre.
\end{abstract}

Under 1990-talet var de så kallade värstingseglatserna ett återkommande inslag i medier. Ungdomar som omhändertagits och placerats av socialtjänsten skulle ombord på ett segelfartyg samtidigt bryta med en destruktiv livsföring, tränas i samlevnad och få en viss seglingsutbildning. Inte minst vållade destinationerna, som var typiska semestermål som Medelhavet och Västindien, indignation - de seglade helt enkelt i för varma vatten (Hydén 1993). Det förekom även en hel del rapporter om olika incidenter såsom våld, skadegörelse, rymningar och alkoholkonsumtion av ungdomar och anställda. Det mest kända vårdföretaget med denna inriktning "Donna Sails« återupptog verksamheten år 2002, och återigen tog medier en synnerligen aktiv roll. Samhällsprogrammet Kalla fakta i TV 4 lät nämligen några medarbetare följa med ungdomar och anställda ombord och

Torbjörn Forkby är doktorand vid institutionen för socialt arbete, Göteborgs universitet. Hans kommande avhandling handlar om framväxten av alternativ till institutionsvård för ungdomar så kallade "hemmaplanslösningar«: framväxten, vårdideologin och praktiken. i hamnar. Det mest intressanta med reportaget är dock inte vårdformen som sådan, utan den speciella berättarteknik som reportaget stöptes $i$ - dokusåpaformatet. ${ }^{1}$

Artikeln anknyter till det ökande intresse det finns för hur sociala problem, utsatta grupper och socialt arbete skildras i medierna, och då särskilt till diskussionen om mediernas roll i konstruktionen av identiteter, stereotyper och social mening (Blomberg et al. 2004). Forskningen om hur ungdomar och i synnerhet hur "problemungdom" behandlas i medierna har dock till övervägande del begränsat sig till pressens rapportering. Televisionens stora genomslag och komplexa uttrycksform, gör det angeläget att ägna detta medium större uppmärksamhet. ${ }^{2}$

1 Detta ledde till en viss diskussion på Internet, där Marco Espvall inledde med "Bra TV? Kanske. Men är det moraliskt försvarbart?" (Espvall 2003)

2 Enligt MMS tittarundersökning hade de två avsnitten av det aktuella reportaget i Kalla fakta 920 tusen respektive 630 tusen tittare. Av dessa var omkring 50 tusen mellan 12 - 24 år. (källa: www.mms.se). 
Syftet med artikeln är att undersöka hur bilden av vårdformen, ungdomarna och de anställda konstruerades samt om och i så fall vilka förklaringar till och förståelse för ungdomarnas situation som gavs. Syftet bryts ned till frågeställningarna; Hur framställs karaktärerna och deras inbördes relationer? Hur ser det övergripande berättartemat ut? Vilka signifikanta händelser skildras och vad fyller dessa för funktion i förhållande till berättartemat och karaktärerna?

\section{Alternativ (till) institutionsvård för ungdomar}

Utvecklingen av seglatser under 1990-talet kan ses mot bakgrund av en kritik av traditionell institutionsvård. ${ }^{3}$ Vårdeffekten hos denna bedömdes som låg eller till och med negativ, och det fanns en upprördhet över att inte ens de mest kvalificerade institutionerna förmådde att hantera de mest vårdkrävande ungdomarna. I medierna fördes den så kallade värstingdebatten. Seglatserna var samtidigt en del av en mer omfattande utveckling av olika alternativ till institutionsvård som skedde inom öppenvården under 1990-talet (Socialstyrelsen 1998). Statliga utvecklingsmedel till-

3 I en artikel i Svenska Dagbladet 1995-05-09 sägs att Ragnar Götestam, då på Socialstyrelsen, under sin tid på Stockholms socialtjänst, var den som "kläckte idén». Han menar i artikeln att »ungdomarna kommer bort från sin kriminella miljö, det är lättare att motivera dem till studier när de får praktisk användning av kunskaperna direkt, till exempel matematik för att navigera». skapades 1994, bland annat för att utveckla mellanvårdsalternativ. ${ }^{4}$

Som vårdform erbjöd seglatserna något annat än vad den traditionella institutionsvården erbjöd. Dessa seglatser förmodades attrahera de ungdomar som institutionsvården misslyckats med och/eller dem som inte bedömdes passa in i den. Även om seglatserna kan ses som en alternativ institutionsvård, och inte ett alternativ till institutionsvården är det vård som uppfattas ske i en friare och öppnare form. ${ }^{5}$

\section{Skildring av ungdomar i medier}

Ungdomar är i första hand ett objekt i medierna, må det vara som ideal i tappningen vacker och sexuell och med framtiden för sig, ung och rebellisk och hotfull som problem $\mathrm{i}$ kriminaljournalistikens persongalleri av offer och förövare eller som identitetssökande med osäker framtid (Feilitzen 1989). Ungdomarna konstrueras som medieobjekt dels i underordnade roller i förhållande till vuxna aktörer och dels som symboler för vuxenvärldens förhoppningar och farhågor. Genom att diskutera ungdomen kan olika grupper och intressen markera sina revir och muta in sina kunskapsområden (Bjurström 1997, Frykman 1988).

4 Som ett ödets ironi sammanfaller dock utvecklingen av alternativ till institutionsvård för ungdomar med att den minskning som skett sedan 1940-talet av denna form av placering, brutits till förmån för en relativt kraftig ökning under 1990-talet (Lundström \& Vinnerljung 2001, Sallnäs 2000).

5 I och för sig likt "utflyttad institutionsvård" såsom Hasselas omtalade fjällvandringar, även om dessa har en institution som de utgår från. 
I sin analys av amerikanska filmer om ungdomar såg Lewis (1992) ett genomgående konformistiskt drag som återförsäkrade och gav förhoppningar om bevarande av vissa (gruppers) kulturella värden. Hebdigde (1988 s. 16 - 36) identifierar två huvudsakliga framställningsformer av ungdomar i medierna: youth-as-troble och youth-as-fun. När det gäller problemungdomar tycks det finnas en väl förankrad moralisk uppdelning mellan de oförskyllt drabbade "offren" som är värdiga samhällets stöd och deras motsvarighet, de ovärdiga kriminella ungdomarna "förövarna». Mediernas skildring av den »hotfulla ungdomen« ger lätt upphov till föreställningar och tolkningar som börjar leva ett eget liv och få konsekvenser i sig själva genom moralisk indignation/panik (Cohen 1972, Lindgren 2000, Ohlsson 1997). I diskussionen om ungdomen har idéer och positioner flyttats fram och motats tillbaka med hjälp av, eller motarbetade av, mediernas särskilda logik. Detta visar sig särskilt när det handlar om den intima kopplingen mellan medier, ungdomar och brott. Denna synes å ena sidan vara frikopplad från brottslighetens verkliga omfattning och utbredning och å andra sidan ha stor betydelse för att skapa hot och rädslor förknippade med just denna brottslighet (Estrada 1999, Pollack 2001).

Färre studier finns av hur den sociala barn- och ungdomsvården skildras i medierna. Lundström (2004) pekar dock på en tudelning mellan en vardagsrapportering och framställningen av vissa särskilt uppmärksammade barnavårdsfall. Vardagsrapporteringen återger barnet $\mathrm{i}$ allmänhet som passivt, oskyldigt och som det osynliga barnet som drabbats av olyckliga omstän- digheter (Andersson 2004, Lundström 2001). De särskilt uppmärksammade fallen var däremot på ett helt annat sätt föremål för en dramatisk iscensättning. Dessa utgjorde snarast en projektionsduk mot vilken olika moraliskt/kulturellt baserade farhågor och förhoppningar kunde gestaltas. I och med att ungdomar befinner sig mellan barndom och vuxenhet, kan de lätt göras till föremål för såväl offer/barn som en förövare/vuxendiskurs. Lars-Christer Hydén (1993) som analyserat tidningsdebatten om värstingseglatserna under 1990-talet, menar att den hämtade näring från dessa två motsatta positioner. En från vilken ungdomarna sågs som ansvariga brottslingar för sina (straffbara) handlingar och en annan som betraktade dem som oansvariga offer (barn) och som därmed borde vårdas. Författaren Göran Odbratt (2003 s. 122 - 179) visar i en slags fallstudie av en ungdom från en värstingseglats, att medierna inte verkade sky några kostnader för att få de rätta bilderna och hur de återgav en berättelse som verkar ha varit bestämd på förhand. Sättet att skildra ungdomarna och vårdformen möjliggjordes av att den senare förklarades som ett angrepp på makten i form av socialtjänstemän och politiker.

\section{Mediegenrer}

Norman Fairclough (1995) menar att man måste förstå medierna utifrån dess konkurrensutsatta position på en marknad. I den senmoderna världen förpackas information i en säljande kostym och blir till en handelsvara för att i första hand attrahera konsumenter. Information har i många fall blivit till »infotainment», i vilken nyhetsförmed- 
lingen blandas med underhållning och ofta även ges drag av informell, vardaglig konversation. Han ägnar också genrebegreppet stor uppmärksamhet, som han definierar som ett socialt ratificerat sätt att handla i och genom diskurs. Mittel (2001) menar att en genre kan ses som en diskursiv praktik, alltså en sammankoppling av tankesystem, begreppsliga kategorier och praktiker. Turner skriver (2002 s. 5) "Genre helps to frame audience expectations. For the television viewer, genre plays a major role in how television texts are classified, selected and understood". Alla mediegenrer favoriserar ett visst slags sätt att framställa personkaraktärer, en viss form av dramatisering/berättande, ett visst sätt att iscensätta och ett visst bildspråk (Berger 1992, Neal 2002). En genre är dock inte ett hermetiskt tillslutet system av föreskrivanden, utan det sker ett ständigt utbyte över gränserna genom vilket den hybridiseras.

Även om det finns många likheter mellan en dokusåpa och "flugan på väggen» dokumentären, skiljer sig de åt genom tonläget (Bruzzi 2001). Dokusåpan tenderar att prioritera underhållning framför den sociala kommentaren, den fokuserar på karaktärerna, ofta presenterade med förnamn redan i påannonseringen, och i motsvarande grad tonar den ned deras sociala roller. Det finns en dragning mot det dramatiska, sensationella och mot konflikter. Dokusåpan förvandlar tittarna till smygtittare och aktörerna, som tänks leva sina vanliga liv, till »hyperordinära» vanliga människor.

Kalla faktas skildring av seglatsen kan ses som ett stilexperiment genom att olika element sammanförts. Ett av de mest uppenbara inlånade stildragen från dokusåpan möter tittaren redan i påannonseringens "vem får stanna kvar, och vem måste lämna båten" (ön, farmen eller vad det må handla om) och skapar en spänning och intensitet i den "verklighet" som programmet ger sig ut för att skildra. Vi finner också uflugan på väggen" dokumentären exempelvis genom speakerröst som kommenterar och förklarar, men själv syns journalisten aldrig framför kameran. Han är närmast en ledsagare som för oss in i ett annars slutet rum. Vi möter också ett bekännelseformat som lånat mycket sitt stildrag från det slags personliga kommentarer som deltagare i Robinson eller Big Brother gör. Intervjufrågor är bortredigerade och deltagarna uppfattas ge ut av sitt innersta till synes utan uppmaning.

\section{Programmet}

I reportaget skildras fyra ungdomar och sex anställda i olika situationer såsom avresa från Sverige, ankomst till båten, under olika perioder ombord på båten och i hamnar. Det innehåller även två inslag där ungdomar intervjuas när de kommit tillbaka till Sverige. Programmet sändes med en åtföljande studiodiskussion i två halvtimmeslånga avsnitt under mars månad 2003. Av programtiden utgjordes 44 minuter av skildringen av själva seglatsen och studiodiskussionen av åtta minuter. Övriga inslag bestod av presentation av whallåa» och studioreporter, en trailer där nästa avsnitt presenterades, uppspelning av röster från telefonsvarare och en animation. Tillsammans upptog dessa drygt fyra minuter av programtiden. Programmet leddes av en studioreporter som utöver presentationen även ansvarade för diskussionen om seglat- 
sen där projektledaren utfrågades. Utöver studioreportern medverkar ytterligare två speakerröster, en manlig och en kvinnlig. Den manliga rösten framstår tillhöra den huvudansvarige för skildringen av seglatsen, medan den kvinnliga ger information om olika vårdformer i Sverige och om seglatser under 1990-talet.

\section{Analysmodell}

Det finns en omfattande metodologisk diskussion rörande om, varför och hur man kan analysera ett diskursivt material (t.ex. Fairclough 2003, Silverman 1993). Gemensamt för många olika former av diskursanalyser synes vara en noggrann och upprepad "närläsning" av empirin, en ambition av att koppla samman det specifika med någon form av övergripande struktur och inte minst att poängtera själva analysstegens betydelse (Antaki et al. 2002). Etermediets "multimodalitet" gör det till komplext forskningsobjekt genom dess kombination av olika kommunikativa tekniker såsom det verbala, det visuella, ljudsättning och ikonografi (Kress \& Leeuwen 2001). Fairclough (1995 s. 84 - 94) avser en liknande komplexitet med begreppet polyfoni en intertextualitet där ljud, bild och övrigt semiotiskt material såväl kan understödja som motsäga varandra.

Efter att ha tittat på programmet noggrant ett par gånger för att få en känsla av helheten i framställningen, transkriberades talet ordagrant. Transkriptionen av tal och ljudsättning fördes därefter in i en matris i vilken programmet indelades i (62) sekvenser. De olika sekvenserna bestämdes genom att väga samman konversations- tema, ljudsättning och bildpresentation. Sekvensindelningen var viktig för att kunna identifiera en narrativ struktur i framställningen. I matrisen noterades vilka aktörer som återfanns i de olika sekvenserna, hur dessa iscensattes genom vad som hände $\mathrm{i}$ bild samtidigt med talet och hur de olika uttrycksformerna samspelade med varandra. I nästa steg spårades karaktärerna genom att studera den position i vilken de framställdes och hur relationerna mellan deltagarna skildrades (vad de uttalade sig om, vem de agerade med, hur det sades och hur de relaterade). En del av analysen handlade också om positioneringens "baksidau, alltså vad som inte berättades om de olika karaktärerna och därmed funktionen för det outtalade. Därefter sökte jag efter mönster och signifikanta händelser i materialet; återkommande teman och hur de framställdes, vilka subjektspositioner som tilldelas aktörerna och vilka övergripande sociala och kulturella spelregler som tematiseras och hur detta skedde.

\section{Inget nytt under solen}

Det är påfallande hur stor överensstämmelse det är mellan Kalla faktas tematisering och hur debatten om vårdformen tidigare förts (se Hydén 1993). Skall den rätteligen beskrivas som en lyx som ungdomarna inte är berättigade till, eller bör den ses som ett välbehövligt alternativ i ett större vårdutbud?

När man studerar reportaget närmare finner man en ganska fast narrativ struktur, ett dramatiskt berättande (Ödeen 1988). Det har ett anslag där den grundläggande konflikten presenteras och karaktärerna 
visas upp, det finns en upptrappning där konflikten stegras till en klimax som sätter allt på sin spets och det finns en nedtoning där konflikten tonas ned. I reportaget finner man emellertid inget definitivt avgörande utan den tredje fasens nedtoning leder fram till ett slags antiklimax som avslutas i ambivalens och oavgjordhet.

\section{Anslaget}

\section{STUDIOREPORTER:}

Välkomna tillbaka till kalla fakta. Minns ni debatten om värstingseglatserna i början på nittiotalet? En hel värld upprördes över att Sverige, för skattepengar, skickade unga kriminella på seglatser $i$ solen. Ska brottslingar verkligen belönas med lyxsemestrar? undrade kritikerna och seglatserna fick ett tvärt slut. Men nu tio år senare har den här oerhört kontroversiella behandlingsmetoden tagits upp igen..$^{6}$ Och kalla fakta var med när den första båten la ut frän Rhodos med två unga killar, Sami och Anders ombord.

En hel värld sägs ha upprörts. Flera gånger poängteras vilken grupp som det handlar om och hur "oerhört kontroversiell" den är. Anslaget inleds genom att exponera det moraliska dilemma som ska anläggas genom programmet; är dessa ungdomar värda denna vårdform? Dilemmat förutsätter en särskild relation mellan en viss kategori människor och en specifik situation. Anslaget levereras i den enkla formen "värsting + segling = lyxsemester" och avses väcka känslomässig indignation. Dynami-

6 Seglatserna bedrevs i och för sig i olika omfattning under stora delar av 1990-talet. ken i programmet handlar om att laborera mellan ungdom som brottsling eller som offer och om seglingen är att betrakta som avkoppling $\mathrm{i}$ solen eller som hårt arbete. Det går inte att undkomma att det i vilket fall handlar om ett särskilt slags kategori av ungdomar. Begreppet "värsting» i olika sammankopplingar används sexton gånger i programmet, såsom värstingseglatser, värstingresor, värstingar. När begreppet "ungdomar" används förknippas detta tolv gånger med ett stigmatiserande epitet, såsom »kriminella ungdomar, ungdomar med missbruksproblem, ungdomar som dömts till vård". Endast två gånger är konnotationen positiv "satsa på ungdomar och ge ungdomar en andra chans». Den enda kategorisering som används relativt fritt från stigmatiserande adjektiv är »killar« som används tolv gånger i framställningen.

Efter en dryg halv minuts introduktion i studion, exponeras de första två centrala karaktärerna Anders och Sami. De får då på cirka tio sekunder vardera vittna om att de är brottslingar.

[Anders avbildas sittande utomhus, i Sverige i regngrått väder]

ANDERS:

Det var väl lite stöld och narkotikabrott och sådär sen var de rättegång idag också som jag fick fortsatt, vad heter de?

SPEAKERRÖST:

Vard

ANDERS:

Fortsatt vård inom socialtjänsten.

SAMI:

[Ny bild. Sami kommer in i bilden, någonstans vid Medelhavet. Han harklar sig och spottar] 
Grovt olaga hot och grovt olaga vapeninnehav sen var det massa andra smågrejer narkotikabrott och stöld.

Genom denna snabba exponering av dem visas att de är »värdiga» epitetet värsting. Därefter får ungdomarna kommentera att de ska iväg och segla. Anders säger att han hoppas att lära sig någonting, åtminstone att segla. Sami hörs säga, under det att han och en av de anställda gör inköp inför avresan, att han varit drogfri tre månader och att: liksom jag ska $i$ alla fall klara en dag till liksom absolut. Karaktärerna presenteras genom att de i tur och ordning får kommentera liknande teman. Detta leder till en uppsättning med två centrala aktörer. Båda två har en likhet i förutsättningarna för varför de är där, men de framställs samtidigt med en dramatisk tacksam olikhet i inställningen till vården och i deras bakgrund. Anders skildras genom programmet som en som inte tar vården på allvar, som undviker svårigheter och som saknar respekt för regler. Sami däremot framställs som mycket mer engagerad i vården, följsam och eftertänksam. Det centrala i narrationen om Sami är tidsmässigt framåtriktad; kommer han att klara av att vara drogfri? Anders är däremot intressant främst genom sin historia. Medan vi knappt får veta något om Samis historia, lyfts Anders fram som exempel på offret - ett barn till missbrukare. Denna bakgrund är också den enda egentliga förklaring som ges till att ungdomar kan hamna i dylika svårigheter. Det är det sensationella och dramatiska som lyfts fram och visas upp lika snabbt som naket. Anders bakgrund skildras på ett närmast exotiserande sätt när han för tredje gången visas i bild och öppnar dörren till det behandlingshem där han bor. Han visar sitt rum för oss varefter en bild på fadern zoomas in.

\section{ANDERS:}

Här är då mitt rum, här har vi då far min. [foto på fadern visas i bild]. Han blev ihjälslagen faktiskt. (..) Ja, han var ju alkoholist så att dom var väl på och festa eller nånting. Vart det väl bråk mellan han och två tjejer så dom bara "tick"klubba ner honom, med en stekpanna. Morsan var knappt aldrig hemma och så där. Var ute och festade (..) istället [för att vara] hemma hos oss och laga mat och grejer. [Bilden övergår från fadern till att zooma in ett foto av ett barn i lågstadieåldern].

Konstruktionen av offret förstärks av att kameran flyttas från fotografiet på fadern, till ett porträtt av Anders - ett skolfoto av leende barn i yngre skolåldern. Detta slags foto, så vanligt i många svenska hem, får sitt symboliska värde i framställningen genom att avslöja att bakom bilden av det leende barnet, som kunde ha varit den egna klasskamraten, dolde sig en stor tragik. Fotot representerar det oskyldiga och osynliga barnet som drabbats av olyckliga omständigheter (Andersson 2004, Lundström 2001).

Det viktigaste i anslaget är att skapa intressanta karaktärer, både i sig själva men främst i relation till varandra. Detta skapar en dramatik som kan locka till fortsatt tittande. Om den allra första karaktärsexponeringen handlar om ungdomsbrottslingen, så inleds därefter en process av karaktärsformning. Vi möter alltså i och för sig 
brottslingar men i olika form genom tillläggsepiteten »botgöraren" Sami och »den tragiske« Anders.

Den tredje delen av anslaget är iscensättningen, ute på båten. Detta görs genom ett nytt filmklipp där Anders dyker i det blågrönt skimrande Medelhavet. Solen står högt på en klarblå himmel. Det är bildmässigt, snyggt och inbjudande. Bildspråket är på denna punkt tämligen entydigt genom hela programmet. Endast få exempel finns på annat, som en vintersegling iförda varma kläder i december. Efter ytterligare några av ungdomarnas dyk visats, flyttas vi ned under däck där två av de anställda diskuterar ungdomarna. I denna scen presenteras dramats centrala intrig genom att de anställda kommenterar de olika karaktärerna och anger temat för det relationsdrama som kommer att bära intrigen.

\section{LÄRARE ANN:}

Sami är ovanligt mogen för att vara arton år (M: precis) och Anders är kanske lite ovanligt omogen. Men han är ändock bara sexton år och har haft väldigt trassliga hem//förhållanden liksom, så det är inte så förvånande

BEHANDLINGSASS. MAGNUS: I/problemet är att han förnekar det själv dà lite grand, att han är sådan, utan han klarar sig minsann [bildbyte där Anders dyker $i$ havet] (...) Men han måste bli till också.

\section{LÄRARE:}

[Suckar] Ja, ja vi får se då [Tittar ut från kajutan mot båten].

Den ena är mogen, den andra omogen och hänger fast i sin historia, fast på ett omedvetet sätt. Därtill kommer det viktigaste med denna sekvens nämligen anslaget av intrigen när Ann ställer sig och tittar ut från kajutan mot båten. En bild hade just visat att Anders dykt i havet och hon säger samtidigt som hon ser bekymrad ut " Ja, ja vi fär se då och ger uttryck för tvivel och en osäker framtid.

Förutom detta slags anslag som görs då programmet inleds, förekommer det i form av programtrailers. Dessa sändes såväl under veckan, innan ett avsnitt och i direkt anslutning till programmet. Genom dessa korta sekvenser exponeras programmets drivande intrig och dess karaktärer. I en av dem visas först några ungdomar som vandrar omkring till synes planlöst i en lägenhet, det är som om de väntar på något. En elgitarr tonar upp och drar med sig en rockmusik. Man får känsla av att något avgörande är på gång. I dessa sekvenser samspelar text, ljudsättning och bild för att ge spänning och dramatik för att väcka intresse.

[I bild visas skylttexten: Anders får ett ultimatum]

LÄRARE ANN:

Vi ska prata med dig

ANDERS:

$\mathrm{Nu}$ ?

LÄRARE ANN:

$\mathrm{Nu}$

ANDERS:

[Anders i närbild]

Jag fatt. jag fattar ingenting

[I bild visas skylt med texten: Några skickas hem efter ett återfall]

UNGDOM RALF:

[Ralf i närbild]

Dom sätter på mig handbojor och så sen så åkte till polisstationen. 
SAMI:

[Sami i närbild, Medelhavet i bakgrunden]

Lås in mig för i helvete så slipper jag ens och tänka för fan.

I en mycket komprimerad form presenteras framställningens spänningsmoment; vilka ungdomar kommer att vara kvar? Programtrailern ger också närbilder av tre ungdomar som också gestaltar tre olika karaktärer; den (spelat) oförstående som har svårt att anpassa sig, den som faller igenom och den som kämpar med sitt inre. Det är kanske främst anslag som detta som direkt leder associationerna till en annan genre än dokumentären. Programmet handlar inte primärt om att få kunskap om vad denna vårdform innebär, utan om att få delta ombord för att följa med i ett spännande drama. Frågan om vilka som kommer vara kvar ställs på samma sätt som om det vore en trailer till TV-programmet Robinson. Den ger också på samma sätt en försmak om att nästa program innehåller spännande situationer och upplösningar. Detta sägs ännu tydligare då första Kalla faktaprogrammet avrundas med: Stämningen ombord hårdnar. Får seglingen fortsätta efter fylla och knivrån? [...] Vi fortsätter och följa Sami och dom andra ungdomarna på värstingbåten i Medelhavet i Kalla fakta nästa torsdag.

\section{Upptrappning}

Efter anslaget kan dramat börja utvecklas. Nästa fas, upptrappningen, dominerar första programavsnittet och den första hälften av det andra. Denna fas har formen av ett relationsdrama där de olika karaktärerna och relationerna dem emel- lan accentueras. Detta presenteras genom situationer som följer ett slags stegringslogik. En central sådan som återkommer vid summeringar och trailerinslag är när Sami, Anders och behandlingsassistenten Magnus sitter i kajutan. De diskuterar vad som kommer att hända när en ny ungdom anländer från Sverige. Relationsdramat accentueras genom att Sami framställs som hjälpsökande och "värdig» behandlingen. Han får också mycket positiv feedback från de anställda. Anders däremot framställs som oengagerad i behandlingen och nedvärderas. Scenen är också tacksam då deltagarna själva iscensätter de två antagonistiska betraktelsesätt för vad vårdformen innebär, som såväl Kalla faktas reportage som den tidigare mediedebatten byggts upp kring. När Sami nästan som ett mantra upprepat, att Donna Sail inte är till för dem som är rädda att arbeta, säger Anders tvärtom att han inte tycker att de gjort något ansträngande. Detta får den anställde att agera för att neutralisera det legitimitetshot det skulle vara om Anders mening blev gängse. Neutraliseringen går till genom att hänvisa till att Anders undviker arbete, alltså är lat. Genom detta flyttas fokus från verksamhetens karaktär till ungdomens moraliska brister.

\section{SAMI:}

Donna Sail liksom det är inte för vem som helst, utan det är för såna som inte är rädda för å arbeta (..) inte rädda för och arbeta åå:: (Anders skrattar) ta $i$ lite och liksom arbetsvilliga å vilja förändra sitt liv å (Magnus: ja)

ANDERS:

Jag tycker inte vi gör någonting. Vi har skol- 
uppgifter, vi har ju inte gjort någonting som är speciellt ansträngande.

MAGNUS:

Näe, sen kan man ju undvika det som är ansträngande också (Sami: ja, precis)

ANDERS:

Ja, men även om jag skulle vilja jobba då, så är det ju inte ansträngande det //skulle ju inte ta

SAMI:

// nej, men för helvete

MAGNUS:

// [ohörbart] när det gäller din bit de är ju faktiskt fullt upp bara med att få dig att ta hand (Anders: ${ }^{*} a^{*}$ ) om dig själv. Tycker du att du har pluggat nu så att du klarar av de här teoriprovet väldigt enkelt till exempel? Tycker du att du har pluggat hårt (..)? Du hade inte en susning. Du satt ju där som en nolla i fejset där i morse när vi gick igenom. [Anders går från båten]

Den anställde anför ett exempel för att visa att det är Anders som inte engagerar sig tillräckligt genom att han inte klarade dykarcertifikatsprovet: du satt ju där som en nolla $i$ fejset. Anders blir upprörd och går från båten. Magnus kommer senare och menar att han vill hjälpa honom och att han inte menar Anders är en nolla, utan såg ut som en nolla i fejset. Strax efter detta klipper programmet in en sekvens där behandlingsassistenten och Sami sitter på en restaurang och den förre säger att det var skönt att slippa från båten och Anders en stund. Upptrappningen går mot en oundviklig upplösning där allt sätts på sin spets. I Kalla fakta framställs detta genom att Anders får ett ultimatum, en månads prövotid, som ska avgöra om han får vara kvar eller inte. Två av de anställda sitter på en balkong med Anders. Han svarar dem med viss förställning av rösten, som kan tolkas så att han håller viss distans. Scenen avslutas med att Alf, något oväntat, frågar om Anders vill ha en kram och de omfamnar varandra för att sedan vara klara.

\section{LÄRARE ANN:}

Om du ska vara här (Anders: $\left.{ }^{*} j a a^{*}\right)$ så måste de ju finnas någon mening med de (A: * ehhjaa*). Om du märker och vi märker och Christer hör, eftersom vi har kontakt med honom och rapporterar till honom, att "det här är kanske inte rätt plats för Anders". Han kanske behöver nåt annat (Anders: ${ }^{*} j a a^{*}$ ). Då är det ju ingen mening med att fortsätta och gå och tjafsa här eller hur BEHANDLINGSANSVARIG ALF:

Anders, (Anders: aa jag ska) ja men Anders, (Anders: ja) det är till din hjälp att vi gör så. För Anders det är ingen, ingen som vill att du ska lämna projektet (Anders: öh, nej). Vill du ha en kram av mig?

ANDERS:

Nej, ja för kom hit då. Fan vad jobbig du är (Alfskrattar).

ALF:

Okej, klar

Därpå följer en bildsekvens med några vardagsbilder från båtlivet för att vi sedan ser Anders hemma i Sverige igen. Han kommenterar att han tycker att det nya behandlingshem han placerats på passar honom bättre. Anders ser då lugnare ut $\mathrm{i}$ ansiktet och sitter och spelar gitarr som det visar att han är riktigt duktig på och han säger: helt ärligt så strunta egentligen i vad dom sa, för att jag tyckte att "det här det behöver inte jag". Man får intrycket av att han blivit frisläppt från 
den karaktär han placerats inom tidigare i skildringen, och fick nu visa andra sidor.

Denna klimax byggs upp genom ett slags crescendo där tre situationer sammanförs. Den första är den ovanstående. Den andra handlar om att ungdomarna stjäl skeppskassan genom att hota en av de anställda med kniv, och den tredje om att två av ungdomarna tar 250 euro från en klädbutik. De senare blir dömda till ett villkorligt fängelsestraff och utvisning från Grekland. Här bryts framställningen av att studioreportern frågar projektansvarige: Ja, knivrån och utvisning hur mycket sånt här ska man acceptera?

\section{Anfallslinje och försvarsposition iden moraliska kampen}

\section{STUDIOREPORTER:}

Kan du förstå att det sticker i ögonen på folk de här med sol och bad?

PROJEKTLEDARE:

Ja, det förstår jag också, men det beror också lite på en missuppfattning att man bara skall sola och bada. Det är ju inte riktigt så. Det kommer ju, det syns ju också i programmet att det är ganska tufft. (..) Efter ett tag så är det ju inte så kul längre och segla (Sr: $\mathrm{mm}$ ). Jag menar, det kan vara jättekul i en vecka men, det är dåligt väder också. Det regnar och det stormar och det är kallt och det är vinter även i Medelhavet.

Den moraliska kampen avgörs genom en strid om definitioner. När reportern eller »allmänhetens röst « från programmets telefonsvarare kategoriserade vårdformen som "sol å bad", försökte projektledaren omde- finiera kontexten till vinter och kyla. "Det är vinter även i Medelhavet " sammanfattar väl dessa ansträngningar. När studioreportern om och om igen frågade om det inte var en form av belöning eller lyx menade projektledaren med samma envishet att det handlade om ett hårt arbete. I den stund en av dem skulle lyckas med att få vårdformen inordnad i sin egen definition, skulle den moraliska kampen vara vunnen. Man kan kalla de två för den varma och den kalla. Den varma associationskedjan kopplades genom att länka samman varmt - sol - bad - semester - Medelhavet - avkoppling $=$ lyx/belöning. Den kalla var den omvända kall - vinter - snöslask - november -Sverige - hårt arbete $=$ vardag $/$ det ordinarie. Den kalla kännetecknade den gråa vardagen och den varma det extra och lyxiga. Det som möjliggjorde debatten var trots allt att de båda hyllade samma grundantagande nämligen att ungdomarna inte skulle få komma $i$ åtnjutande av det varma och belöningen, utan det var genom hårt och slitsamt arbete de skulle räddas.

\section{Nedtoning}

Efter studiodiskussionen återstår en fjärdedel av programmet, och en ny fas tar vid. I denna blir den nyanlände David en central karaktär. Framställningen drivs nu inte längre mot ett crescendo, utan stämningen lugnas ned och relationsdramat är heller inte så polariserat. Vi möter eftertänksamma ungdomar som reflekterar över sina liv, och som visar att de är osäkra på hur framtiden kommer att gestalta sig. Om den förra fasen drevs i en upptrappning mot ett crescendo, liknar denna mer ett avkling- 
ande coda som fångar upp lite grand av det föregående men som framförallt tonar ned de mest högljudda trumpetstötarna. Här är inte klimax slutpunkten utan snarare antiklimaxens oavgjordhet och eftertänksamhet. Ungdomarnas samtal med varandra lyfts fram istället för deras olika positioner, som här när de talar om rädslan för att bli besviken.

\section{SAMI:}

Jag vill ju inte hoppas för mycket du vet. Det är jobbigt och bli besviken du vet. Man, jag fär hopp lite mycket ibland kanske, jag vet inte. Går det åt helvete så lär, jag blir, ta till droger eller nånting liksom men ändå försöka fortsätta liksom ändå.

DAVID:

Näe, jag känner fan också igen mig i de där du säger alltså. Om jag förväntar mig nånting som man liksom känner att "uff det här kommer jag bli skitglad över liksom och så där", då blir man rädd lite grand lite grand liksom och då tar man till de här alltså att "näe det kommer inte att bli sådär liksom och då vänder man på de och ser de som att "de är det värsta som kommer hända". För då vet man liksom att då står man inte där sen och är så där, så jävla besviken och fattar liksom "va fan har hänt" liksom utan på slutet är ändå så liksom så:.: På nåt sätt såär man van bli besviken alltså.

I nedtoningsfasen finner vi en annan dominerande relationstyp, istället för att grundas på en olikhet som driver narrationen framåt, konstrueras relationerna genom likhet och ömsesidighet. Detta gäller såväl hur relationen mellan ungdomarna skildras som mellan ungdomar och anställda.
Tittarna får höra när David läser sin Life Story som han antar är till för att ledarna ska få en bättre bild av vilka ungdomarna är. Denna livsberättelse ter sig som en form av brotts- och droghistoria, inte helt olik en social utredning. Det är den vardagliga lunken som skildras, där ungdomar och anställda delar en gemensam tillvaro dag för dag. Men, även om denna fas har ett lugnare och mer sökande tempo, finns det ett drama som tematiseras. Till skillnad från det externa dramat mellan karaktärerna, har detta lokaliserats till ungdomarnas inre. Ungdomarna framställs som kämpande med sin uppväxt och sina dåliga förutsättningar för att om möjligt få en framtid. Vi får höra Sami och Alf språka om vad behandling är, eller kanske snarare hur Sami undervisas i en behandlingens diskurs:

ALF:

Men vad är det du håller på med just nu?

SAMI:

Behandling

ALF:

Och vad är det som händer där då?

SAMI:

$\mathrm{Mm}$, jag vet, inte fan vet jag, jag vet inte vadåöhh

ALF:

Ja, men du lär ju känna dig själv lite bättre eller hur?

SAMI:

Ja, det är sant

ALF:

Så säger han de

SAMI:

"Lära känna mig själv (..) lite mer " [skriver ned i Vägvalsboken]. Jag vill ha jobb, jag vill ha lägenhet. Ja, det skriver jag fan i mig. 
Även den avslutande studiodiskussionen tar en lugnare form, så till den grad att studioreportern mot slutet överger den kritiska position som hon hittills intagit. Istället blir studioreportern hjälpsam och samspelande med projektledaren. Studioreportern öppnar med deltagande att: så att det är stötestenar överallt verkar det som. Projektledaren får då till slut acceptans för sin positionering som engagerad ungdomsarbetare som kämpar mot en oförstående allmänhet, och underförstått en jagande journalistkår.7 Denna nya frågeposition blir än mer tydlig i den allra sista frågan, då den indignerade allmänhet som programmet hittills företrätt, själv görs till ett kritiserat objekt. Från att ha varit rättmätigt känslomässigt upprörda, förvandlas de till avundsjuka: Vad skulle du vilja säga till dom som (.) är avundsjuka på seglatser?, och projektledaren ges återigen möjlighet att beteckna ungdomarna som offer och att det inte alls är någon lyxresa.

\section{Avslutande reflektioner}

Värstingseglatser har varit en följetong i mediernas rapportering alltsedan de startade under 1990-talet. De kan närmast betecknas som mediala fynd på grund av dess dramatiska potential och förutsättningar till att gestalta olika moraluppfattningar. Kalla faktas skildring följer en medial "tradition" genom att tematisera vårdformen i spänningsfältet mellan

7 Vid två tidigare tillfällen menade projektledaren att rädsla för uppmärksamhet i medierna skrämde socialtjänsten från att placera ungdomar i verksamheten. en behandlings/omsorgs- och en straff/ ansvarsdiskurs. Åsa Kroon (2001 s. 268) menar att det i mediedebatter bildas en särskild debattdynamik som skapas genom återkommande kommunikativa rörelser. Denna dynamik styr på ett förgivet taget sätt mediernas behandling av ett ämne, och re-/producerar i sin tur ett visst perspektiv att förstå världen ur. Kalla Faktas dokusåpaliknande skildring kan ses som en förtätning av en sådan dynamik. Den möjliggjordes genom elaborerande mellan skilda positioner i rummet mellan karaktärer, över tid genom narrationens utveckling och med hjälp av olika modaliteter i ljud och bild. Ungdomar och anställda gjordes intressanta som karaktärer i ett relationsdrama, till vilket publiken i tillskriven roll av allmän opinion, inbjöds på ett alldeles särskilt sätt. Denna opinion konstruerades parallellt med framställningens fortskridande som en »tredje röst" och tillskrevs den lilla människan mot makten (Svensson 2001 s. 234 - 247). Genom att göra den allmänna opinionen till en aktiv rollinnehavare fick journalisten såväl legitimitet för sina frågor som utökade positioneringsmöjligheter. I första hand gav denna röst journalisten berättigande att ifrågasätta seglatserna som »lyxresor". Men, när ungdomarna mot slutet mer entydigt förstods som offer och sökande en oviss framtid, kunde den opinion programmet så aktivt medverkat till att konstruera, själv kritiseras för att vara oförsonlig och oförstående.

Behandlingen av värstingseglatserna är emellertid inte det enda, eller det mest vanliga sättet det sociala arbetet med ungdomar skildras i medierna. Berättartekniken, genom vilken personerna och hän- 
delserna förvandlades till karaktärer $\mathrm{i}$ en känslomässigt engagerande intrig, följer snarare en dramaturgi för hur sensationella händelser rapporteras (Ghersetti 2000). För det sociala arbetet verkar dessa ha sin motsvarighet i skildringen av vissa särskilt uppmärksammade barnavårdsfall, till skillnad från en vardaglig, faktasökande gestaltning (Lundström 2004). Möjligen kan man i mediernas behandling av det sensationella finna var gränserna går för det som moraliskt kan accepteras i den sociala ungdomsvården. Om det är så är det tyvärr snarare närheten än avståndet till arbetshus, tuktinrättningar och uppfostringsanstalter och som delar in problemungdomar i de värdiga och de ovärdiga, som slår en.

\section{Transkriptionskoder}

$\begin{array}{ll}{[\mathrm{l}]} & \text { Bildinformation } \\ (\ldots .) & \text { Utelämnat tal } \\ { }^{*}{ }^{*}{ }^{*} & \text { Tal med förställd röst } \\ / / & \text { en talare avbryter en annan } \\ \text { oerhört } & \text { Emfas } \\ \text { "Lära ... " } & \begin{array}{l}\text { Citerar sig själv eller andra i } \\ \text { talet }\end{array}\end{array}$

\section{Referenser}

Andersson, Gunvor (2004) „Pressens bild av barns missgärningar«. i Helena Blomberg, Christian Kroll, Tommy Lundström, Hans Swärd (red.) Sociala problem och socialpolitik i massmedier. Lund: Studentlitteratur.

Antaki Charles, Billig Michael, Edwards Derek, Potter Jonathan (2002) Discourse Analysis Means Doing Analysis: A Critique of Six Analytic Shortcomings. Hämtad 04042002 från Internet: www.shu.ac.uk/daol/.

Berger, Arthur Asa (1992) Popular Culture Genres. Theories and Texts. London: Sage.

Bjurström, Erling (1997) Högt \& lågt: smak och stil i ungdomskulturen. Umeå: Boréa.

Blomberg, Helena, Kroll Christian, Lundström Tommy, Swärd Hans, (red.) (2004) Sociala problem och socialpolitik. Lund: Studentlitteratur.

Bruzzi, Stella (2001) „Docusoaps». i Glen Creeber (red) The Television Genre Book. London: Brittish Film Institute.

Cohen, Stanley (1972) Folk Devils and Moral Panic. London: MacGibbon and Kee.

Espvall, Marco (2003) Kalla faktasåpan. Hämtad
06042003 från Diskussionsgrupp: www.mediekritik.nu.

Estrada, Felipe (1999) Ungdomsbrottslighet som samhällsproblem: utveckling, uppmärksamhet och reaktion. Akad avh. Stockholms univ.: Stockholm.

Fairclough, Norman (1995) Media discourse. London: Edward Arnold.

Fairclough, Norman (2003) Analysing discourse: textual analysis for social research. New York: Routledge.

Feilitzen, Cecilia von (1989) „Ungdom och medier: klass, kommersialism och kreativitet : en antologi». i Helena Wulff (red.) Ungdomar som problem, ideal och identitetssökare. Stockholm: Centrum för masskommunikationsforskning Stockholms univ.

Frykman, Jonas (1988) Dansbaneeländet: ungdomen, populärkulturen och opinionen. Stockholm: Natur och kultur.

Ghersetti, Marina (2000) Sensationella berättelser: en studie av nyheter från Angola 1987 och om prinsessan Diana 1997 i dagstidningar, radio 
och TV. Akad avh. Göteborgs univ.: Göteborg.

Hebdige, Dick (1988) Hiding in the light: on images and things. London: Routledge.

Hydén, Lars-Christer (1993) »The social construction of juvenile deliquency: Sailing in cold or hot water." Young vol. $1 \mathrm{nr} 4$.

Kress, Gunther R, van Leeuwen Theo (2001) Multimodal discourse : the modes and media of contemporary communication. London: Arnold.

Kroon, Åsa (2001) Debattens dynamik: hur budskap och betydelser förvandlas i mediedebatter. Akad avh. Linköping: Tema Univ.

Lewis, Jon (1992) The road to romance and ruin: teen films and youth culture. New York: Routledge.

Lindgren, Sven-Åke (2000) Den hotfulla njutningen. Att etablera drogbruk som samhällsproblem. Stockholm: Symposion Graduale.

Lundström, Tommy (2001) „Ett haveri i socialtjänsten eller i pressen? Om barnmisshandel i kvällstidningar». i Gunvor Andersson, Karin Aronsson (red.) Haverier i social barnavård? Fem fallstudier. Stockholm: Centrum för utvärdering av socialt arbete/Gothia.

Lundström, Tommy (2004) "Mellan vardag och dramatik». i Helena Blomberg, Christian Kroll, Tommy Lundström, Hans Swärd (red.) Sociala problem och socialpolitik i massmedier. Lund: Studentlitteratur.

Lundström, Tommy, Vinnerljung Bo (2001) "Omhändertagande av barn under 1990-talet«. i Marta Szebehely (red.) SoU 2001:52. Välfärdstjänster i omvandling, forskarantologi frän Välfärdsbokslutet. Stockholm: Fritzes.

Mittel, Jason (2001) „A Cultural Approach to
Television Genre Theory." Cinema Journal vol. $40 \mathrm{nr} 3$, s. 3 - 24.

Neal, Steve (2002) „Genre and Television«. i Glen Creeber (red.) The Television Genre Book. London: Brittish Film Instititute.

Odbratt, Göran, Tunbjörk Lars (2003) Dom alla reflektioner om socialt arbete. Stockholm: Journal.

Ohlsson, Lars B. (1997) Bilden av den hotfulla ungdomen. Om ungdomsproblem och om fast ställandet och upprätthållandet av samhällets moraliska gränser. Akad avh. Lund: Lunds Universitet.

Pollack, Ester (2001) En studie i medier och brott. Akad avh. Stockholm: Stockholms univ.

Sallnäs, Marie (2000) Barnavårdens institutioner: framväxt, ideologi och struktur. Akad avh. Stockholm: Stockholms univ.

Silverman, David (1993) Interpreting Qualitative Data. Methods for Analysing Talk, Text and Interaction. London: Sage.

Socialstyrelsen (1998) Individ- och familjeomsorgens arbete med ungdomar: en uppföljning av utvecklingen sedan 1993. Stockholm: Socialstyr.

Svensson, Christian (2001) Samtal, deltagande och demokrati i svenska TV-debattprogram. Akad avh. Linköping: Tema Univ.

Turner, Graeme (2002) »The Uses and Limitations of Genre». i Glen Creeber (red.) The Television Genre Book. London: Brittish Film Institute.

Ödeen, Mats (1988) Dramatiskt berättande. Om konsten att strukturera ett drama. Stockholm: Carlssons. 


\section{Summary}

\section{Rehabilitation of juveniles as a docusoap}

In the late 1980s the birth of a new kind of treatment practice was witnessed in Sweden. Criminal or drug-abusing boys were sent on sailing trips by the social welfare departments as a form of rehabilitation. This gave rise to an intense debate in the mass media during the 1990s, largely because the trips took the boys to typically touristy places such as the Mediterranean or the West Indies. In 2003 the news and documentary programme Kalla fakta ("Cold facts') broadcast a documentary on the treatment practice, merged into the genre of the docusoap. In the article discourse analysis is used to analyse the hybridization of the genres and how this affected the narrative and the characters.

The article concludes that it seems the sailing trips can be seen as a real find for media reporting on delinquency and social work, since they facilitate the exposition of moral and cultural values. If the youngsters were regarded as victims they were to be regarded as worthy of the treatment, but if on the other hand they were pictured as criminals, they should be punished and are not worthy of this kind of "luxury". The judgement of this moral dilemma was to be made from position of public opinion, a position that was concomitantly constructed from the programme itself. This kind of depiction, however, is not the only way social work or delinquency is treated in the mass media, but a format used for the extraordinary. In this, the youngsters and their relations to the staff were moulded into a dominant narrative structure that emphasized the sensational and the deviant. In sum, a picture was created to fit into a certain kind of square format; both were invited into the public opinion and constructed in certain restricted way, related to certain moral values. 